\title{
Monitoring of Urine and Serum Cellular Enzymes in the Chromium Electroplating Workers
}

\author{
H. M. EL-Shafei* \\ Alsaafa Building, block no: 68, flat no: 17, 42131, Port Said, Egypt
}

\begin{abstract}
Chromium compounds are potent toxic and carcinogenic substances. With respect to toxicity, hepatic and renal toxicity have been reported both in workers and in animals exposed to Chromium (VI). Chromium (VI) compounds induce DNA damage in vivo and in cultured cells as well as the cytotoxicity evaluated by the leakage of lactate dehydrogenase. The present study reports the cytotoxicity of chrome platers who are employed from 8 to 48 years in electroplating industries at Damietta city. Blood samples were collected and estimated for aspartate amino. The study revealed that there is a significant elevation in the level of Aspartate Amino Transferase (AST) and Alanine Amino Transferase (ALT), Alkaline Phosphatase (ALP), Lactate Dehydrogenase (LDH), Creatine Phosphokinase (CPK). Chromium concentration in erythrocytes was used to monitor hexavalent Chromium exposure CPK and transaminases and a decrease in total protein in serum. The results of the study suggest that Chromium (VI), a hepatotoxic chemical may perhaps damage the plasma membrane resulting in leakage of enzymes in to the serum of chromeplaters.
\end{abstract}

Keywords: Chromium compounds; Serum; AST; ALT; LDH; ALP; CPK; Total protein

\section{Introduction}

Chromium (Cr) is one of the eight metals in the top 50 priority list for toxic substances by the Agency for Toxic Substances and Disease Registry (ATSDR 2003). The majority of Chromium in the environment exists in two valence states: trivalent Chromium Cr (III) and hexavalent Chromium Cr (VI) [1]. Chromium (III) in its biologically active form [Glucose Tolerance Factor or (GTF) a dinicotinato Chromium (III) glutathione - like complex], facilitates interaction of insulin with its receptor site, influencing glucose, protein and lipid metabolism. Thus Chromium (III) is essential for animals and human beings [2] In contrast, $\mathrm{Cr}(\mathrm{VI})$ compounds can actively penetrate cell membrane through channels for isoelectric and isostructural anions, such as $\mathrm{SO}_{4}^{2}$ - and $\mathrm{HPO}_{4}^{2}$ - channels [3,4] Insoluble chromates are up taken via phagocytosis [5]. Cr (VI) is a strong oxidizing agent, and can be reduced through short-lived $\mathrm{Cr}$ intermediates ( $\mathrm{Cr}(\mathrm{V})$ and $\mathrm{Cr}(\mathrm{IV}))$ to the stable trivalent state. The reactions of $\mathrm{Cr}$ (VI) with biological reductants, such as ascorbate and thiols, often generate free radicals, which in turn activate $\mathrm{O} 2$ and produce reactive oxygen species (ROS), including hydroxyl radicals, singlet oxygen, superoxide and hydrogen peroxide [6]. Occupational exposure to Chromium occurs mainly through inhalation and dermal absorption in the working environment, including Chromium compound manufacturing, electroplating, leather tanning, welding, chrome plating, the manufacture of dyes and pigments, leather and wood preservation, and treatment of cooling tower water. Smaller amounts are used in drilling mud, textiles, and toner for copying machines. Dermal exposure to Chromium may occur during the use of consumer products that contain Chromium, such as wood treated with copper dichromate or leather tanned with chromic sulfate [7]. Prolonged exposure to airborne or solid, liquid Chromium compounds lead to chronic toxic effects on humans. The diseases are nasal septum perforations, ulceration's of skin surfaces, rhinitis, liver damage, pulmonary congestion, edema, nephritis, intestinal lung and gastric cancers, irritation of gastrointestinal mucosa, chronic total parental nutrition, (Symptoms like weight loss, hypoglycemia), respiratory effects, congestion and hyperemia, chronic rhinitis [8]. There are only few reports of the health effects of chronic exposure to hexavalent Chromium in developing countries. Hence the present study was under taken to monitor the Chromium (VI) induced cytotoxicity in workers exposed to electroplating by evaluating the leakage of few marker enzymes into the serum. The indicators examined included urinary Chromium (U-Cr), Aspartate Amino Transferase (AST), Alanine Amino Transferase (ALT), Alkaline Phosphatase (ALP), Lactate Dehydrogenase (LDH), Creatine Phosphokinase (CPK) and Total Protein (TPr).

\section{Materials and Methods}

\section{Sample}

The study was carried out in August 2010 and involved 84 male workers, who were divided into 2 groups. The first group consisted of 42 workers who were recruited from 12 electroplating factories in Damietta, Egypt; this group was considered as Chromium electroplating workers and subdivided into two groups (II and III) according to the duration of exposure. The second group comprised 42 office workers with no exposure to Chromium and was considered as a reference group. They were working at an office in Damietta city unrelated to the Chromium-electroplating factories. The reference group subjects were matched for age and socioeconomic status (income, area of residence) with the Chromium - electroplating workers. Demographic information and work history and habits (smoking status, alcohol consumption) of all subjects were obtained through a questionnaire.

\section{Laboratory methods}

All laboratory equipment was well cleansed by soaking in $10 \%$ nitric acid for 24 hours and rinsing thoroughly with deionized water

*Corresponding author: H. M. EL-Shafei, Alsaafa Building, block no: 68, flat no: 17, 42131, Port Said, Egypt, Tel: 00201273709137; E-mail: hshafei154@yahoo.com

Received March 23, 2012; Accepted April 16, 2012; Published April 20, 2012

Citation: EL-Shafei HM (2012) Monitoring of Urine and Serum Cellular Enzymes in the Chromium Electroplating Workers. J Bioengineer \& Biomedical Sci 2:116. doi:10.4172/2155-9538.1000116

Copyright: @ 2012 EL-Shafei HM. This is an open-access article distributed under the terms of the Creative Commons Attribution License, which permits unrestricted use, distribution, and reproduction in any medium, provided the original author and source are credited. 
[9]. The same cleansing procedure was applied to the polypropylene containers used for venous blood and urine sampling and for storing the serum.

\section{Urine test}

A urine sample was collected from the Chromium - electroplating workers in metal-free polyethylene bottles at the end of 8-hour working day for measuring urinary creatinine concentration. All the samples once collected were kept on ice and delivered within the same day to the laboratory with minimal vibration.

\section{Blood test}

Samples of $5 \mathrm{~mL}$ whole blood were collected in two test-tubes at the end of the working day at the same time as urine sampling. Sample collection followed the guidelines described by Cornelis et al. [10]. In the $1^{\text {st }}$ blood tube serum was separated by centrifugation at $2500 \mathrm{rpm}$ for $20 \mathrm{~min}$ at $25^{\circ} \mathrm{C}$ to assess liver function using standard methods $[11,12]$. All the biochemical markers were estimated using a random access analyser (RA-50, Bayer).

\section{Measurement of Chromium concentration in erythrocytes and urine}

In the $2^{\text {nd }}$ blood tube blood was centrifuged for $10 \mathrm{~min}$ at 2000 rpm to isolate erythrocytes for determining Chromium levels. The erythrocytes were washed with Phosphor-Buffered Saline (PBS) for three times. Chromium concentrations in erythrocytes and urine were measured by Inductively Coupled Plasma Method / Mass Spectrometric Method (ICPS - MS).The standard curve was fitted with linear leastsquares method. The detection limit of Chromium was $0.2 \mu \mathrm{g} / \mathrm{L}$. The recovery of standard addition was $95-98.8 \%$. The concentration of Chromium in erythrocytes was corrected for hematocrit for each subject.

Serum ALT and AST were used to assess hepatic inflammation (kits supplied by Human Gesellschaft fur Biochemica und Diagnostica). Alkaline Phosphatase (ALP) was used to assess cheloestasis (kits supplied by Chema Diagnostica). The determination of Lactate dehydrogenase and creatine phosphokinase activity were used to assess Cytotoxicity. The determination of serum total protein was used to assess synthetic function of liver (protein kits produced by Chema Diagnostica). For internal quality control human-based control sera were used (QN.0050CH, Chema Diagnostica).

\section{Statistical analysis}

Numerical data were expressed as mean and Standard Deviation (SD). Student $t$-test was used to compare the mean levels of parameters between the Chromium exposed and reference groups. The chi squared test was used to compare the abnormal frequencies of liver function tests between groups. The level of statistical significance was established at 0.05 with a statistical power of $80 \%$.

\section{Results}

Some background parameters of the Chromium- electroplating and reference groups are presented in Table 1. Due to the matching, the mean age of Chromium- electroplating and reference group were similar at 41.6 (SD 2.08) and 43.28 (SD 1.98) years respectively.

Table 2 presents the activities of serum Aspartate Amino Transferase (AST) and Alanine Amino Transferase (ALT) in control group and chromoplaters. There were no significant differences in age,

\begin{tabular}{|l|c|c|c|c|c|c|}
\hline \multirow{2}{*}{ characteristic } & \multicolumn{3}{|c|}{ Reference group } & \multicolumn{3}{c|}{ Exposed group } \\
\cline { 2 - 8 } & N & Rang & Mean \pm SD & N & Rang & Mean \pm SD \\
\hline Number & 42 & - & - & 42 & - & - \\
\hline Age(year) & - & $18-64$ & $41.16 \pm 2.08$ & - & $19-65$ & $43.28 \pm 1.98$ \\
\hline Smokers & - & - & - & 28 & - & - \\
\hline $\begin{array}{l}\text { Duration of } \\
\text { employment(year) }\end{array}$ & - & - & - & - & $2-48$ & $25.52 \pm 1.93$ \\
\hline
\end{tabular}

Table 1: Characteristic of the reference and exposed groups.

\begin{tabular}{|l|c|c|}
\hline \multicolumn{1}{|c|}{ Group } & AST (IU/L) Mean \pm SD & ALT (IU/L) Mean \pm SD \\
\hline I Control Control $(n=42)$ & $27.84 \pm 1.22$ & $28.15 \pm 1.22$ \\
\hline $\begin{array}{l}\text { II Exposed chromoplating } \\
(8-16)(n=9)\end{array}$ & $40.33 \pm 1.35^{*}$ & $40.22 \pm 1.52^{*}$ \\
\hline $\begin{array}{l}\text { III Exposed chromoplating } \\
(17-48)(n=33)\end{array}$ & $48 \pm 0.44^{*}$ & $48.76 \pm 0.42^{*}$ \\
\hline
\end{tabular}

*Values are expressed as Mean \pm SD for ' $n$ ' in each group

For statistical evaluation, the values of group I were compared with gp II and III $\mathrm{p}<0.01$

Table 2: Activities of serum Aspartate Amino Transferase (AST) and Alanine Amino Transferase (ALT) in control group and chromoplaters.

gender, smoking status, alcohol consumption between the two groups ( $\mathrm{P}$ values $>0.05)$.

Table 3 presents the activities of serum Lactate Dehydrogenase $(\mathrm{LDH})$ and Creatine Phosphskinase (CPK) in control group and chromoplaters. The results of the present study demonstrate that the chromate induced cytotoxicity as estimated by the leakage of $\mathrm{LDH}$, ALP, protein, AST and ALT into the serum.

Table 4 presents the levels of serum Alkaline Phosphatase (ALP) and Total Protein (TPr) in control group and chromoplaters. The results of the present study demonstrate that the chromate induced heart and liver function as estimated by the leakage ALP, Total protein into the serum.

Table 5 presents the Chromium concentrations in erythrocytes and urine (in $\mu \mathrm{g} / \mathrm{L}$ ) in electroplating workers and control group. In electroplating workers, the median of Chromium concentration in erythrocytes was about 1.5 times higher than that in control subjects $(\mathrm{P}<0.001)$. The median of Chromium concentration in urine in 8-16 years exposed was about 6 times higher than that in control group, where in 17-45 year exposed was about 20 times higher than that in control group, urinary Chromium concentration of $>64.5 \mathrm{nmol}$. $\mathrm{mmol}^{-1}$ creatinine $(\mathrm{P}<0.001)$. After stratification by potential confounding factors such as gender, age, smoking status and alcohol consumption, significant differences remained between exposed workers and control subjects except for the subjects less than 15 years old $(\mathrm{P}=0.11)$. In addition, among electroplating workers, the Chromium concentration of erythrocytes and urine in smokers was significantly higher than that in non-smokers $(\mathrm{P}<0.05)$.

\section{Discussion}

In this study, we investigated the effects of chronic Chromium exposure on liver in electroplating workers. Chromium concentration in erythrocytes was used to monitor hexavalent Chromium exposure. The results showed that Chromium concentration in erythrocytes in electroplating workers was significantly higher than that in control subjects. The current results indicated that electroplating workers experienced chronic occupational Cr (VI) exposure, which induced oxidative stress and liver damage. The interaction of metal ions with the lipids of biological membranes might have significant 


\begin{tabular}{|l|c|c|}
\hline \multicolumn{1}{|c|}{ Group } & LDH (IU/L) Mean \pm SD & CPK (IU/L) Mean \pm SD \\
\hline I Control Control $(n=42)$ & $70.65 \pm 5.73$ & $134.22 \pm 5.26$ \\
\hline $\begin{array}{l}\text { II Exposed chromoplating } \\
(8-16)(n=9)\end{array}$ & $129.11 \pm 22.5$ & $148.30 \pm 5.82$ \\
\hline $\begin{array}{l}\text { III Exposed chromoplat- } \\
\text { ing }(17-48)(n=33)\end{array}$ & $296.66 \pm 14.35^{*}$ & $187.81 \pm 5.62^{*}$ \\
\hline
\end{tabular}

*Values are expressed as Mean \pm SD for ' $n$ ' in each group

For statistical evaluation, the values of group I were compared with gp II and III, $p<0.01$

Table 3: Activites of serum Lactate Dehydrogenase (LDH) and Creatine Phosphskinase $(\mathrm{CPK})$ in control group and chromoplaters.

\begin{tabular}{|l|c|c|}
\hline \multicolumn{1}{|c|}{ Group } & ALP $($ IU/L) Mean \pm SD & Total protein(g/dl) Mean \pm SD \\
\hline I Control Control $(n=42)$ & $95.76 \pm 3.39$ & $6.76 \pm 0.08$ \\
\hline $\begin{array}{l}\text { II Exposed chromoplating } \\
(8-16)(n=9)\end{array}$ & $136.33 \pm 17.5^{*}$ & $6.2 \pm 0.23^{*}$ \\
\hline $\begin{array}{l}\text { III Exposed chromoplat- } \\
\text { ing(17-48) }(n=33)\end{array}$ & $199.09 \pm 10.94^{*}$ & $4.98 \pm 0.100^{*}$ \\
\hline
\end{tabular}

*Values are expressed as Mean \pm SD for ' $n$ ' in each group

For statistical evaluation, the values of group I were compared with gp II and III, $\mathrm{p}<0.01$

Table 4: Levels of serum Alkaline Phosphatase (ALP) and Total Protein in control group and chromoplaters.

\begin{tabular}{|l|c|c|}
\hline \multicolumn{1}{|c|}{ Group } & $\begin{array}{c}\text { Chromium in Erythro- } \\
\text { cyts }(\boldsymbol{\mu g} / \mathbf{L})\end{array}$ & Chromium in urine $(\boldsymbol{\mu g} / \mathbf{L})$ \\
\hline I Control Control $(\mathrm{n}=42)$ & $1.41 \pm 0.26$ & $3.53 \pm 0.23$ \\
\hline $\begin{array}{l}\text { II Exposed chromoplating } \\
(8-16)(n=9)\end{array}$ & $1.1 \pm 0.35$ & $20.12 \pm 6.4^{*}$ \\
\hline $\begin{array}{l}\text { III Exposed chromoplating } \\
(17-48)(n=33)\end{array}$ & $4.19 \pm 0.14^{*}$ & $64.02 \pm 4.32^{*}$ \\
\hline
\end{tabular}

*Values are expressed as Mean \pm SD for ' $n$ ' in each group

For statistical evaluation, the values of group I were compared with gp II and III, p $<0.01$

Table 5: The chromium concentration in erythrocytes $(\mu \mathrm{g} / \mathrm{L})$ and urine in control group and chromoplaters.

consequences for the structural and functional properties of cells. Cell membranes may be damaged due to peroxidation of unsaturated fatty acids, genetic material may be modified or hormonal composition of a given individual may be changed [13]. Elevations in the activities of Serum Creatine Kinase, Lactate Dehydrogenase, Transaminases and Alkaline Phosphatases when compared to controls could be due to disturbances in heart and liver function. A significant increase in the activity of Glutamic Oxaloacetic Transaminase and Glutamic Pyruvic Transaminase in Chromium (VI) exposed workers is indicative of disturbance in liver function. Elevated blood transaminase is induced by heavy metals have also been reported [14]. Creatine Kinase activity was reported to be increased 10 fold in lung carcinoma cell lines and in progressive states of cancer [15] a significant decrease in the level of protein is observed in chromeplaters exposed to Chromium for 16-48 years [16]. Studied the effect of trivalent and hexavalent Chromium compounds on rats' transaminase, urea and creatinine levels in the serum of Chromium poisoned animals. They have found that enlargement of the proximal tubule of the kidney with a flattening of the epithelial lining and a slight vacuolation of the hepatocytes with the progressive damage in liver, with the enlargement of central veins and sinusoids. Liver morphological alterations were further increased when the period of Chromium (VI) exposure was extended at 60 days. Cytotoxicity caused by potassium dichromate was estimated by the leakage of lactate dehydrogenase from the cells was previously reported by Susa et al. [17]. As suggest by Holzer and Duntze [18] the mechanisms behind the chemical modification of enzymes might include phosphorylation, adenylation, ADP ribosylation, oxidation of thiol groups and the respective reverse reactions i.e. all these reactions remain to be tested for the effect of Chromium on them. The decreased level of serum protein in Chromium (VI) exposed group workers could have been due to proteinuria and nephropathy. Liver is the major site of protein synthesis and hence the observed defect in liver cells would have resulted in decreased synthesis of proteins. In vitro and in vivo experiments indicate that unlike inorganic forms of Chromium (III), Chromium (VI) as a chromate anion [19]. On the other hand the elevation of ALPase localized in the cell membrane of liver cells was reported in animals treated with chromate [20]. Consistent with previous findings, Chromium concentration in erythrocytes was significantly higher in electroplating workers than that in control subjects in this study. The value $(4.19 \mu \mathrm{g} / \mathrm{L})$ was also comparable to previously reported $4.3 \mu \mathrm{g} / \mathrm{L}$ in electroplating workers [21]. In comparison, higher Chromium concentration (4.9 to $6.1 \mu \mathrm{g} / \mathrm{L}$ ) has been reported in chrome-plating workers [22].

\section{References}

1. Nickens KP, Patierno SR, Ceryak S (2010) Chromium genotoxicity: A doubleedged sword. Chem Biol Interact 188: 276-288.

2. Grevatt PC (1998) Toxicological Review of Hexavalent Chromium. U.S Environmental Protection Agency, Washington, DC, USA.

3. Alexander J, Aaseth J (1995) Uptake of chromate in human red blood cells and isolated rat liver cells: the role of the anion carrier. Analyst 120: 931-933.

4. Chiu A, Katz AJ, Beaubier J, Chiu N, Shi X (2004) Genetic and cellular mechanisms in chromium and nickel carcinogenesis considering epidemiologic findings. Mol Cell Biochem 255: 181-194.

5. Codd R, Dillon CT, Levina A, Lay PA (2001) Studies on the genotoxicity of chromium: from the test tube to the cell. Coordin Chem Rev 216-217: 537-582.

6. Wang S, Leonard SS, Ye J, Ding M, Shi X (2000) The role of hydroxyl radical as a messenger in $\mathrm{Cr}(\mathrm{VI})$-induced p53 activation. Am J Physiol Cell Physio 279: C868-C875

7. Agency for Toxic Substances and Disease Registry (ATSDR) (1998) Toxicological Profile for Chromium. U.S. Public Health Service, U.S. Department of Health and Human Services, Atlanta, GA, USA.

8. Lippman M (1991) Book on Asbestos and Mineral Fibres. Elsevier Publishers, USA.

9. Pizent A, Telišman S (1996) Analysis of reference materials for serum copper and zinc by flame-AAS. Atom Spectrosc 17: 88-91.

10. Cornelisa R, Heinzow B, Herber RFM, Christensen JM, Poulsen OM, et al. (1995) Sample Collection Guidelines for Trace Elements in Blood and Urine. Pure \& Appl Chem 67: 1575-1608.

11. Ješi R, et al. (2001) Modern functional diagnostics in liver disease. Archives of Gastroenterohepatology 20: 35-38.

12. Morgan DJ, Elliott SL, Gabriel H (1991) Quantitative liver function test: A realizable goal. Can J Gastroentrol 5: 77-85.

13. Pesti M, Gazdag Z, Belágyi J (2000) In vivo interaction of trivalent chromium with yeast plasma membrane, as revealed by EPR spectroscopy. FEMS Microbiol Lett 182: 375-380.

14. Rajanna B, Chapatwala KD, Vaishnav DD, Desaiah D (1981) Changes in the ATPase activities in tissues of rats fed on cadmium. J Environ Biol 2: 1-9.

15. Sell S (1990) Cancer markers of the 1990s. Comparison of the new generation of markers defined by monoclonal antibodies and oncogene probes to prototypic markers. Clin Lab Med 10: 1-37.

16. Laborda R, Díaz-Mayans J, Núñez A (1986) Nephrotoxic and hepatotoxic effects of chromium compounds in rats. Bull Environ Contam Toxicol 36: 332 336.

17. Susa N, Ueno S, Furukawa Y, Sugiyama M (1996) Protective effect of vitamin E on chromium (VI)-induced cytotoxicity and lipid peroxidation in primary cultures of rat hepatocytes. Arch Toxicol 71: 20-24.

18. Holzer H, Duntze W (1971) Metabolic regulation by chemical modification of enzymes. Annu Rev Biochem 40: 345-374. 
Citation: EL-Shafei HM (2012) Monitoring of Urine and Serum Cellular Enzymes in the Chromium Electroplating Workers. J Bioengineer \& Biomedical Sci 2:116. doi:10.4172/2155-9538.1000116

Page 4 of 4

19. Merritt K, Brown SA (1995) Release of hexavalent chromium from corrosion of stainless steel and cobalt-chromium alloys. J Biomed Mater Res 29: 627-633.

20. Chorvatovicová D, Ginter E, Kosinová A, Zloch Z (1991) Effect of vitamins C and $E$ on toxicity and mutagenicity of hexavalent chromium in rat and guinea pig. Mutat Res 262: 41-46.
21. Qu Q, Li X, An F, Jia G, Liu L, et al. (2008) CrVI exposure and biomarkers: Cr in erythrocytes in relation to exposure and polymorphisms of genes encoding anion transport proteins. Biomarkers 13: 467-477.

22. Gambelunghe A, Piccinini R, Ambrogi M, Villarini M, Moretti M, et al. (2003) Primary DNA damage in chrome-plating workers. Toxicology 188: 187-195. 